\title{
Dynamic Modelling of Power Transmission Systems of Transport Means
}

\section{Dinamičko modeliranje sustava prijenosa snage kod sredstava prijevoza}

\author{
Grzegorz Peruń \\ Silesian University of Technology \\ Katowice, Poland \\ e-mail: grzegorz.perun@polsl.pl
}

\section{Summary}

The article presents the concept and up to now developed stages of the simulation program for the analysis of dynamic phenomena occurring during the operation of power transmission systems of various means of transport. Currently completed stages of work allow simulation of drive systems with cylindrical gear or planetary gear. The starting points for the implementation of the assumed goal were earlier developed by author considering two independent dynamic models of drive systems with a simple single-stage cylindrical gear and with a planetary gear. Naval and vessel power transmission systems are one example of the fields of application of the developed program. The spread of mechanical propulsion in shipping, which occurred in the nineteenth century, led to different research problems. These include, above all, fuel consumption, which resulted, among others from the efficiency of the entire system. The need to ensure proper performance, avoid unplanned voyage breaks or meet environmental requirements, imposed by increasingly stringent emission standards, results in the search for effective power transmission system solutions and optimization methods for existing ones. One of such methods is dynamic modeling of drive systems, and an example tool that enables the use of this method is the simulation program presented in the article. During development of the concept of the simulation program we admitted the assumption that the model shall enable the determination of dynamic phenomena that occurs in various construction designs of power transmission systems in both - constant and variable conditions of their operation. Thanks to this, the simulation program can be used in two directions of research. The first direction of research is the optimization of newly designed and existing drive systems, and especially the optimization of the construction of toothed gears. It is possible, among others by taking into account the actual, not only assumed, nominal operating conditions. Besides, the dynamic model used by the simulation program allows a wide range of modifications to numerous design features of the system, including the geometry of toothed gear elements. The second direction of research is the development of efficient methods for detecting local damages of system components. Simulation of various combinations of defects in the power transmission system, including damages of gears and bearings, allows also for more effective improvement of present diagnostic algorithms of toothed gears working in power transmission systems of various transport means.

Sažetak

Članak predstavlja koncept dosadašnje razvojne etape programa simulacije analize dinamičkoga modela, koji se događa za vrijeme sustava prijenosa snage različitih sredstava prijevoza. Sadašnje završene etape rada dopuštaju simulaciju sustava poriva cilindričnom opremom ili planetarnim zupčanikom. Polazišnu točku za implementaciju preuzetoga cilja već je ranije razvio autor koji je uzeo u obzir dva neovisna dinamička modela porivnoga sustava s jednostavnom cilindričnom opremom i planetarnim zupčanikom. Pomorski i brodski sustavi prijenosa jedan su primjer primjene razvijenoga programa. Širenje mehaničke propulzije u brodarstvu, koje se dogodilo tijekom devetnaestoga stoljeća, dovelo je do različitih istraživačkih problema. Oni su ponajviše uključivali potrošnju goriva koja je utjecala, među ostalim stvarima, na učinkovitost cjelokupnoga sustava. Potreba da se osigura pravilno izvođenje, izbjegne neplanirani prekid putovanja te da se udovolji zahtjevima zaštite okoliša, nametnuta sve više rastućim strogim propisima i standardima o emisijama, uzrokovala je potragu za učinkovitim rješenjima u području sustava prijenosa snage i metodama njihove optimizacije. Jedna je od takvih metoda dinamičko modeliranje sustava poriva i primjer oruđa koje omogućava uporabu ovoga modela, tj. simulacija problema predstavljena je u ovome članku. Za vrijeme razvoja koncepta programa simulacije uzeli smo u obzir pretpostavku da će model omogućiti određivanje dinamičnoga fenomena koji se događa u različitim projektima konstrukcije sustava prijenosa snage i u konstantnim i u varijabilnim uvjetima njihova djelovanja. Zahvaljujući tome, program simulacije može se upotrijebiti u dva smjera istraživanja. Prvi je smjer istraživanja optimizacija novoprojektiranoga i postojećega porivnoga sustava te posebice optimizacija konstrukcije nazubljenih zupčanika. Drugi je smjer istraživanja razvoj učinkovitih metoda detektiranja lokalnih oštećenja komponenata sustava. Simulacija različitih kombinacija kvarova u sustavu transmisije snage, uključujući kvarove na opremi i ležajevima, također dopušta djelotvornije poboljšanje sadašnjih dijagnostičkih algoritama nazubljenoga zupčanika koji se koristi kod sustava transmisije snage različitih prijevoznih sredstava.

\author{
DOI 10.17818/NM/2020/1.5 \\ UDK 621.8:656 \\ 629.5:621.3 \\ Original scientific paper / Izvorni znanstveni rad \\ Paper accepted / Rukopis primljen: 23. 10. 2019.
}

\section{KEY WORDS}

dynamic model power transmission system toothed gear transport means

\section{KLJUČNE RIJEČI}

dinamički model sustav transmisije snage nazubljeni zupčanik sredstvo prijevoza 


\section{INTRODUCTION / Uvod}

The constant progress of science and the development of various fields of technology contribute to the continuous increase of requirements for the drive systems seen as a whole, as well as for the design of their components. The requirement to meet exact specifications causes the necessity of the application of new approaches and solutions not only for the production of individual parts, sub-assemblies, and assemblies but also for their design methods.

All the above mentioned, also applies to maritime and inland transport means. The mechanical drive allowed for greater performance and a huge advantage over sailing ships, however, it has become a source of numerous design and operating problems. The huge progress in the construction of power transmission systems of vessels has been made over the years, however, many of the long-known problems remain current, or new ones have appeared, e.g. due to the changes in legal requirements, increase of public awareness and expectations of users. It is important to ensure the lowest possible fuel consumption, the lowest noise emission, or the reduction of vibration associated with drive operation. Meeting the growing requirements means that solutions not used before or used in a limited range, such as hybrid power transmission systems, are becoming more widespread. As such, maritime transport used hybrid systems already a long time ago, but today they find applications for completely other reasons. The great possibility of meeting difficult requirements is gained in their usage, especially in inland navigation.

Currently, the constructor has at his disposal a large palette of construction materials that he can use to manufacture drive system components. In addition to advances in the branch of materials science, manufacturing technologies for individual parts have also changed significantly over the past few decades. Today, the automation of the production process and systems supporting the management of product and process quality are also widely used.

Meeting the growing requirements for the construction and quality of work of any assemblies is not possible only by the usage of better materials, quality management tools or manufacturing methods. Only a combination of new production technologies, modern materials, and more advanced design methods than once used seems to be the only way to meet increasingly restrictive criteria. It is also necessary to apply operationally oriented design, which takes into account, already at the design stage, the operating conditions of the constructed device.

The toothed gears used in various forms and designs are one of the most important assemblies in power transmission systems next to the engines. This justifies all works on their optimization and diagnostics. These tasks make difficult for the obvious fact that the construction of the power transmission systems of one transport means differs significantly from each other. Toothed gears used in them have a different number of wheels, stages, various ratios. They can be constructed e.g. as gear with cylindrical or bevel wheels, with fixed or rotating axes. In currently manufactured car vehicles, gearboxes are usually in the form of an extended assembly of gear pairs, and the number of different solutions is difficult to estimate.

Dynamic models of toothed gears are known and used for decades. During this time, their computational capabilities have increased significantly. They allow determining the influence of the increasing number of constructional and, less often, operational factors on dynamic phenomena occurring in toothed gears or power transmission systems. Taking into account complexity and variety of design solutions of drive system, cost and time of calculations, the functionality of dynamic models of toothed gears and power transmission systems may be limited in a given situation to the most interesting range of issues.

Simulation research with the use of identified dynamic models allows reducing the number of experimental tests to a reasonable minimum. This is a great advantage of dynamic modeling and is economically justified. On the other hand, the combination of various numerical methods, e.g. presented in the paper simulations with the usage of dynamic models with calculations with a use FEM software, allows for further increasing the efficiency of actions taken at the design stage.

The dynamic model can be used also for the development of efficient methods for detecting local damages of system components. Detection of local damages of gear elements based on analyses of vibration signals generated with dynamic models of simple construction gears is presented in many works, among others in [1, 2]. Gui and Han in work [3] present a vibration model for fault diagnosis of the planetary gear. Planetary gear with tooth root crack of ring wheel was a research object in work [4], whereas an incipient tooth crack on the sun gear was a research topic of work [5]. Simulated signals were the basis for the estimation of the defect level in work [6].

The article presents the assumptions of the simulation program and selected results of research conducted with its use. Their purpose was to use the methods of dynamic modeling for optimization of the power transmission systems construction.

\section{SHORT LITERATURE OVERVIEW OF DYNAMIC MODELS OF TOOTHED GEARS AND POWER TRANSMISSIONS SYSTEMS / Kratak pregled literature o dinamičkim modelima nazubljenih zupčanika i sustava prijenosa snage}

Dynamic models of toothed gears and their practical application is the subject of a significant number of scientific publications. The popularity of these problems among scientific and research centers results from the perception of the models as the useful tools that can use in the design and optimization of the gear construction [7, 8]. Many examples of modeling various phenomena occurring in toothed gears are presented in works $[9,10]$.

A literature review allows for some classifications and systematization of toothed gear models. The following types of models can be distinguished [11]:

discrete, which assumes the impulsive excitations with the frequency of meshing. These models are described by algebraic equations, which include functions depending on the manufacturing inaccuracy $[12,13]$ and the occurrence of any damage. Discrete models allow the diagnosis of a selected gear type, but require full identification, which makes them useless in the operations-oriented design of new constructions of gears;

structural, which can be divided into dynamic models - taking into account the stiffness of the meshing, and kinematic models - assuming the deformability of the meshing.

Another review of models of gears and drive systems, as well 
as details of selected solutions, are presented in the paper [14].

Following the scope of included in models sources of excitations, models of gears are divided into two main groups [11, 15]. The first group includes models that take into account excitations only from the toothed gear and omit interactions between gear and the other elements of the power transmission system. These models usually characterize a very accurate mathematical description of wheel cooperation. This cooperation is the only source of vibrations and dynamic surpluses. Models from this group take into consideration the variable stiffness of the meshing along the line of contact.

The second group contains models of complete power transmission systems with toothed gear. Models in this group take into account the interactions between the toothed gear and other elements of the drive system. Besides toothed gear, models include usually engine (electric motor or combustion engine), driven work machine and intermediate elements such as shafts and couplings. The expansion of functionalities of the model from this group is usually connected with simplifications made in the mathematical description of teeth cooperation. Models often assume a constant stiffness of pair of teeth, equal to the average stiffness along the line of contact.

Taking into account tooth stiffness as a constant value or as a function of time or else angle of wheels rotation leads to the omission of a significant phenomenon, which is temporary lack of contact of teeth in the meshing zone. This phenomenon sometimes occurs in the real gears, with significant pitch deviations, which values are greater than the static deflections of the teeth. Like the pitch deviations, a temporary lack of contact of teeth in the meshing zone changes the total stiffness of meshing. Disregarding the above phenomenon is typical for the simplest models of toothed gears and many models of power transmission systems with toothed gear.

Dynamic models, which take into account changes of tooth stiffness caused by various factors, have wider research applications. For this reason, in various classifications they form a separate group, which includes two significantly different ideas: - models considering the cooperation of toothed wheels as a motion of a block sliding on a palisade of elastic elements of various heights. This approach significantly facilitates modeling of variable stiffness of tooth pair in meshing from many factors required in various studies. These models, called palisade ones, separate the working motion from the vibrating motion and are characterized by simplification of the equations describing the tooth profile, modifications, and various deviations. Palisade models simplify the mathematical notation and the qualitative interpretation of analyzed phenomena. They are a continuation of the idea of modeling of toothed gears initiated by Müller [11, 16];

apparent interference models taking into account the possibility of angular displacement of the cooperating wheels concerning the movement that results from the rotation of the wheels without slipping. This is done by determining the degree of theoretical penetration of the outlines of a pair of teeth in cooperation along the entire line of contact, assuming various errors caused by manufacturing imperfections of wheels, as well as caused by temporary operating conditions of the gear. Teeth interference is determined by the function of time, due to which each pair of teeth is observed in a time interval. The time of observation refers to the transverse contact ratio and results from the design parameters of the gear. Determining the apparent interference for all pairs of teeth in the meshing zone allows the calculation of the total meshing force. It may vary not only along the line of contact but also along the width of the tooth. A detailed description of the model, which is a prototype of models from this group, as well as methods for determining apparent interference is presented, among others in work [11].

The idea of the palisade gear model is continued in many newer models of toothed gears and toothed gears working in power transmission systems. A significant number of advantages of this modeling concept play an important role in this. More well-known examples include models that take into account the non-linear characteristics of bearing stiffness, as well as models adapted to simulate helical gears, which also allow for modification of the tooth profile and flank line. Figure 1 presents the original version of the model, based on the work [11].

On the other hand, the concept of apparent interference has been used in many complex dynamic models of gears and power transmission systems with gear, described e.g. in [17, 18]. Figure 2 presents an example of a model with ten degrees of freedom, consisting of a pair of toothed wheels mounted on shafts, and taking into account both - external and internal sources of excitations acting on the power transmission system [19].

In both the above-described types of models: palisade models and the models based on apparent interference, can be highlighted more expanded versions, which has the possibility of testing toothed gears with helical wheels $[20,21]$. This is a result of applying a phase shift associated with the helical tooth, between elemental cross-sections, modeled as wheels with straight teeth. The number of cross-sections into which the wheels are divided for calculations is usually a compromise between the accuracy and time of the calculations. The theoretical division of the wheels allows for the calculation of possible modification of the tooth line and other factors related to the width of the wheel, e.g. diversity of teeth adhesion across the width, which results from shaft deflection or assembly errors.

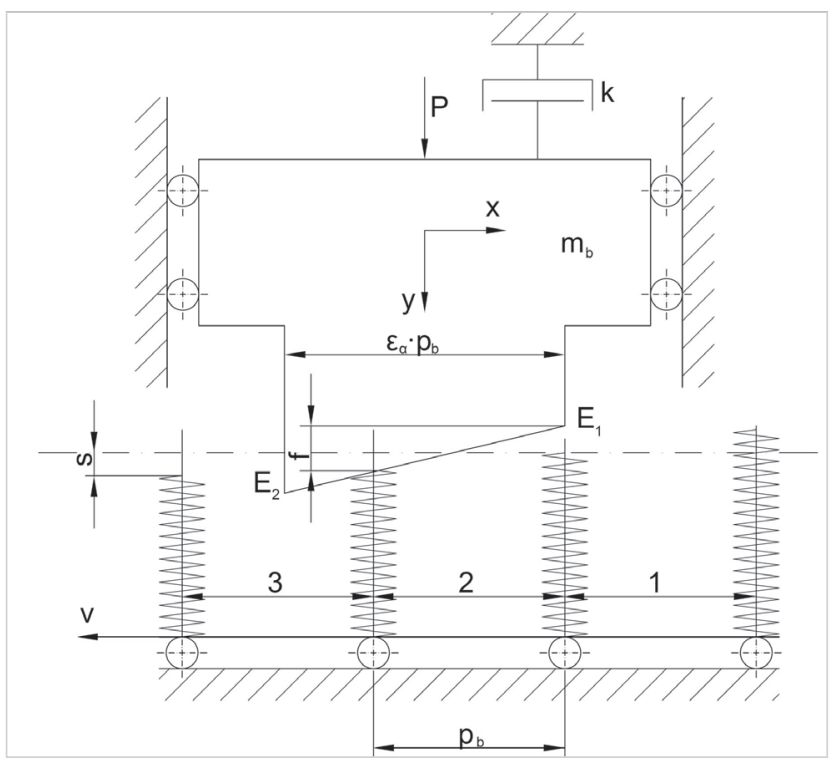

Source: Own study on the basis $[11,16]$

Figure 1 Palisade model of the single-stage toothed gear Slika 1. Model palisadnog zupčanika 


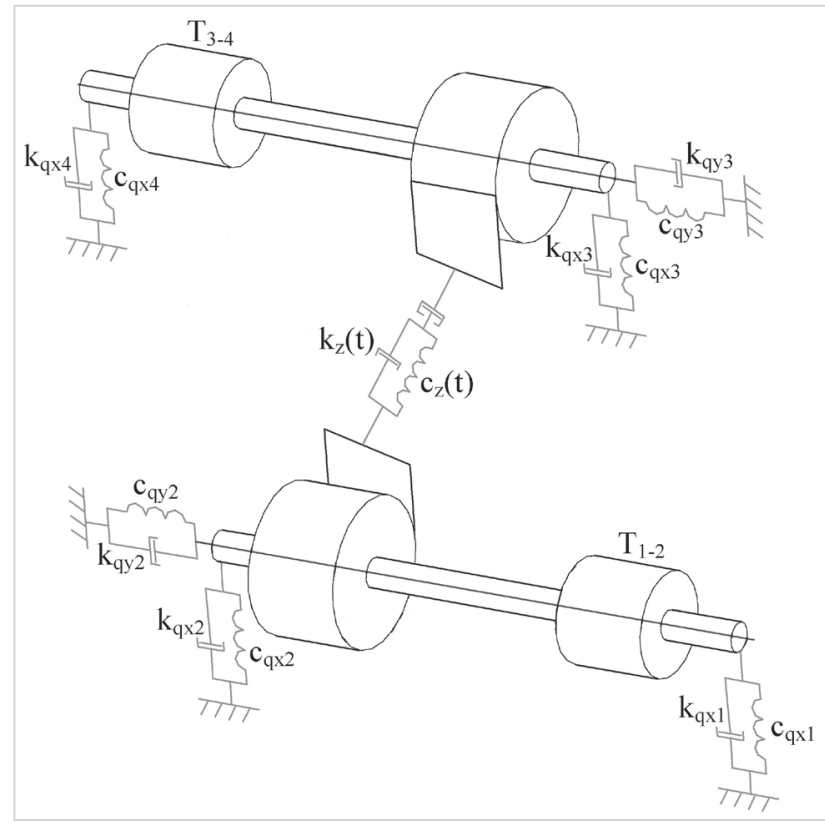

Source: Own study on the basis [19]

Figure 2 Dynamic model with ten degrees of freedom built on the concept of apparent interference

Slika 2. Dinamički model s deset sloboda kretanja sazdan na konceptu prividne interferencije

The simplifications of the models, decisive for their research usefulness, accuracy, and complexity, results from the adopted idea of modeling. The introduction of simplifications also resulted from the obvious lack of possibility of modeling an unlimited number of degrees of freedom of an ideal physical model, as well as from the computational capabilities of computers. However, the development of computer techniques in recent decades has significantly reduced the necessity for excessive model simplifications. Over time, there appear possibilities to include new factors in the calculations and preserve an acceptable calculation time.

According to many works, e.g. [19, 22, 23], for a correct assessment of dynamic phenomena in toothed gears, it should be used dynamic models with an extended description of the meshing properties, damping, stiffness, the torsional and flexural rigidity of shafts. Models should allow simulations with variable speed and load conditions. During simulations of toothed gear work, it is also appropriate to take into account external forces caused by the work of other elements of the power transmission system. Ignoring the impact of external factors on the dynamics of gear work, significantly facilitates its modeling, however, it can contribute to too large differences in the results obtained during simulation of transient states. They cannot be used to determine dynamic phenomena in these states, e.g. during starting or rundown. Considering the above, the models created in recent years are increasingly models of toothed gears working in power transmission systems [24]. There are oft extensions of the earlier, described above concepts.

Unfortunately, among the numerous solutions presented in the literature, there is a very small group of models, which describe toothed gears with more complicated structures, such as planetary gears. One of the few examples of dynamic models of planetary gear available in the literature is the model of $2 \mathrm{~K}-\mathrm{H}$ single-stage planetary gear [16]. It is consistent with the concept of Müller's palisade model, described in one of the previous paragraphs. This single-stage planetary gear model takes into account the radial and tangential movements of discrete masses of moving elements. The stiffness and energy dissipation in meshing zones represent a system of springs and viscous dampers. The model's calculation possibilities and exemplary results of simulation calculations are the subjects of numerous scientific papers and articles, especially in the Polish scientific literature. However, it should be highlighted, that the model does not take into account variable operating conditions and the effects of other drive system components on the work of toothed gear.

The single-stage planetary gear dynamic model takes into account the variable stiffness along the line of contact, damping of vibration in meshing, bearings stiffness and damping and clearances in meshing and bearings. Moreover, allows for simulations of gears with profile modifications and phase shift of the meshing between the planetary wheels and between the sun wheel and the internal gear. A range of the possible number of the planet wheels is from 2 to 6 . The limitation is the ability to perform calculations only at a constant rotational speed.

The mathematical description of the planetary gear enables comparative analysis of various gear design solutions, because the masses of elements, moments of inertia, performance deviations, stiffness, damping, load, rotational speed and time are in the form of dimensionless quantities.

Other models of planetary gears are presented in $[25,26]$. To research non-linear dynamic phenomena in planetary gears, a two-dimensional FEM model and dynamic model were used in [27]. The FEM model allows determination of the meshing stiffness and its variability, edge contacts and for modeling the loss of contact between teeth. The wheels are modeled as masses with known moments of inertia. Meshing stiffness is represented by springs with non-linear characteristics and stiffness depending on the condition of teeth contact. This model is an extended version of the model developed by Lin and Parker [28] and takes into account the phenomenon of loss of contact between teeth and friction forces between surfaces of a mating flank of teeth. The bearings were modeled as springs with linear characteristics.

Creating models of planetary gears and their use is also a research topic of works $[29,30]$. NASA's extensive report from 2001 [27] presents the problem of modeling, properties of a sample model and variable rigidity of planetary gear teeth. The scope of the work includes the presentation of dynamic phenomena in planetary gear, as well as critical factors acting on vibration and noise. The analyses were based again on the model developed by Lin and Parker.

\section{SOURCES OF EXCITATIONS IN TOOTHED GEARS / Ishodišta uzbuđenja kod nazubljenog zupčanika}

The vibroactivity of each device, especially such as the toothed gear, can be formed during the design or prototype stage only when is known the mechanisms of its operation. The operation of toothed gears and power transmission systems accompanies vibrations and noise. They are the result of the objective function and are also caused by various imperfections or by the technical condition of the toothed gear.

Vibroacoustic phenomena can be analyzed by dividing theirs into internal and external sources. This division was made, 
among others at work [11]. The overall level of transmission vibroactivity, as well as the noise generated during their operation, is decided jointly by all sources of excitation. They stimulate the drive system components to vibrate.

Among the internal sources, the largest group create factors shaped at the design stage and related to the proper operation of the toothed gear: cooperation of teeth pairs, tooth impacts, changes of the stiffness of the teeth on the line of contact, changes in friction force due to slips between teeth, as well as those caused e.g. due to insufficient lubrication, bearing interaction and dynamic housing responses. The group of internal factors of excitations in toothed gears is completed by the dimensional and assembly accuracy of the elements, their wear, and damage. Lower classes of the accuracy of gear wheels cause the appearance of significant deviations of the pitch, profile, and line of teeth, which is the reason for the increase of dynamic surpluses. Dion and Moyne used a dynamic model in the study of dynamic phenomena involving gear impacts with one loose gear inside an automotive gear [31].

External factors affecting the operation of a toothed gear are mechanical forces, which include torque disturbances, imbalances, and assembly errors. This group also includes some factors related to the gear operating conditions, such as rotational speed, fluctuations, and load value as well as its changes caused by torque disturbances.

In planetary gears, the structure of the spectrum is more complicated than in ordinary cylindrical gears. In addition to the meshing frequency, additional components with characteristic frequencies are in it visible. They directly relate to the design of the planetary gear and determine different relationships than in cylindrical gears. Analysis of a spur planetary gear involving tooth wedging and bearing clearance nonlinearity, presented in [32], is an example of a problem for analysis with the use of dynamic modeling.

\section{CHARACTERISTICS OF THE SIMULATION PROGRAM / Karakteristike programa simulacije}

At the current stage of implementation, the simulation program works in the Matlab and Simulink computational environments. Numerical research requires the preparation of proper data describing the entire power transmission system, as well as requires connections of prepared functional blocks in the Simulink environment following the characteristics of the drive system. The most important of the prepared blocks are:

block of engine calculations,

calculation block of single-stage toothed gear with cylindrical gear-pair,

calculation block of a planetary gear,

block of clutch calculations,

calculation block of a driven machine.

The engine calculation block comes in two significantly different variations. One of them consists in description only mechanical parameters of engine:

$$
\begin{gathered}
\ddot{\varphi}_{s}=\frac{M_{s}\left(n_{s}\right)-M_{n}}{J_{s}}\left[\mathrm{rad} / \mathrm{s}^{2}\right] \\
n_{s}=\frac{30 \cdot \dot{\varphi}_{s}}{\pi}[\mathrm{rpm}]
\end{gathered}
$$

$\ddot{\varphi}_{s}-$ angular acceleration of the rotor $\left[\mathrm{rad} / \mathrm{s}^{2}\right]$

$M_{s}$ - engine torque determined based on its mechanical characteristics [Nm],

$M_{n}$ - load torque at the rotor $[\mathrm{Nm}]$,

$n_{s}$ - rotor speed [rpm],

$J_{s}-$ mass moment of inertia of the rotor $\left[\mathrm{kg} \cdot \mathrm{m}^{2}\right]$,

$\dot{\varphi}$ - the angular speed of the rotor [rad/s].

The second version of the engine block contains an expanded dynamic model of the electric motor and takes into account its electrical and mechanical parameters and characteristics.

The toothed gear calculation block has been made also in two variants - one allows simulating the operation of a singlestage toothed gear, the other refers to a $2 \mathrm{~K}-\mathrm{H}$ type planetary gear.

The clutch calculation block is in the early stages of development and allows to enter the most basic data. In the final version, it should enable the simulation of the work of different variations of clutches.

In the calculation block of a driven machine is the possibility of the declaration of the moment of inertia and the type of braking moment. Simulation may be realized for a constant or variable value of the load moment. Characteristics of changes can be sinusoidal or rectangular with declared frequency.

Dynamic phenomena in rolling bearings operating in different places of the propulsion system are determined in the simulation program with two alternative calculation methods. They were presented in $[11,21]$. Both allow the determination of non-linear characteristics of shaft neck displacement in the direction of a force.

The equations of motion of each element of the power transmission system were determined from the general formula:

$\frac{d}{d t}\left(\frac{\partial E_{k}}{\partial \dot{q}_{i}}\right)-\frac{\partial E_{k}}{\partial q_{i}}+\frac{\partial E_{p}}{\partial q_{i}}=\hat{Q}_{i}-\frac{\partial D}{\partial \dot{q}_{i}} ; \quad i=1,2, \ldots, n_{d f}$

where:

$E_{k}$ - kinetic energy of the system,

$E_{p}$ - potential energy of the system,

$\hat{Q}_{i}$ - generalized forces,

$D$ - energy dissipation in the system,

$q_{i}$ - generalized coordinates,

$n_{d f}-$ number of degrees of freedom.

During the development of motion equations, experiences obtained from the modeling of drive systems with simple singlestage gear and with a planetary gear have been used [33, 34].

In the expanded dynamic model, calculations of forces in meshing are performed both at successive points on the line of contact, as well in a selected number of points on the width of the meshing of the cooperating wheels. Locations of points on the line of contact are determined in every calculation step based on actual positions, displacements, stiffness, deviations, etc. of gear elements. The model takes into account the variability of rotational speed and load, what is the effect of the interactions of toothed gear and other elements of the power transmission system. This extends the possibilities of the model and makes possible calculations of system work in transient states.

The determination of the total force in every single meshing is carried out depending on the type of meshing, according to Figures 3 a and 3 b. Developed model, base on Müller's concept 
of the palisade dynamic model, and allows for simulations of wheels e.g. with modified tooth lines, as well as wheels with helical teeth, local damages or wear of working surfaces. The illustrations show the characteristic points on the line of contact in two cases: for meshing of two external gears and meshing of internal gear pair.

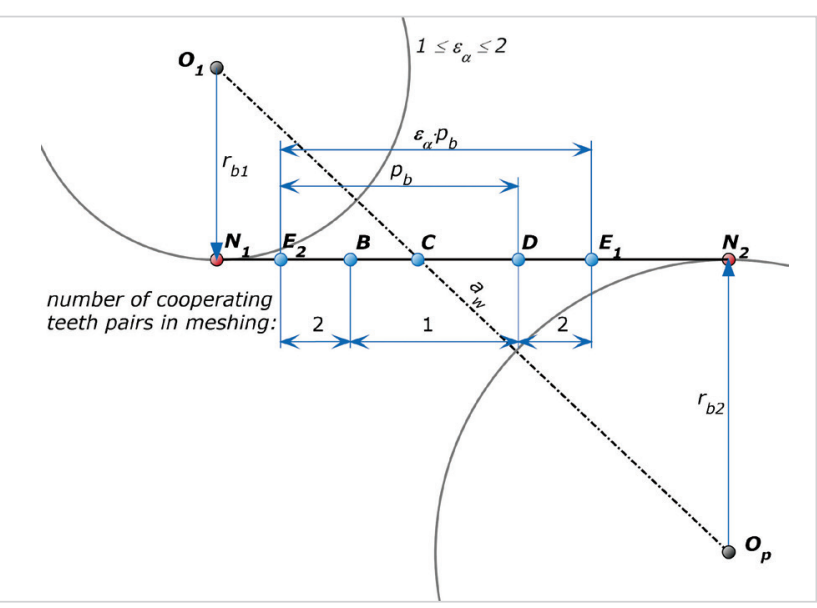

a)

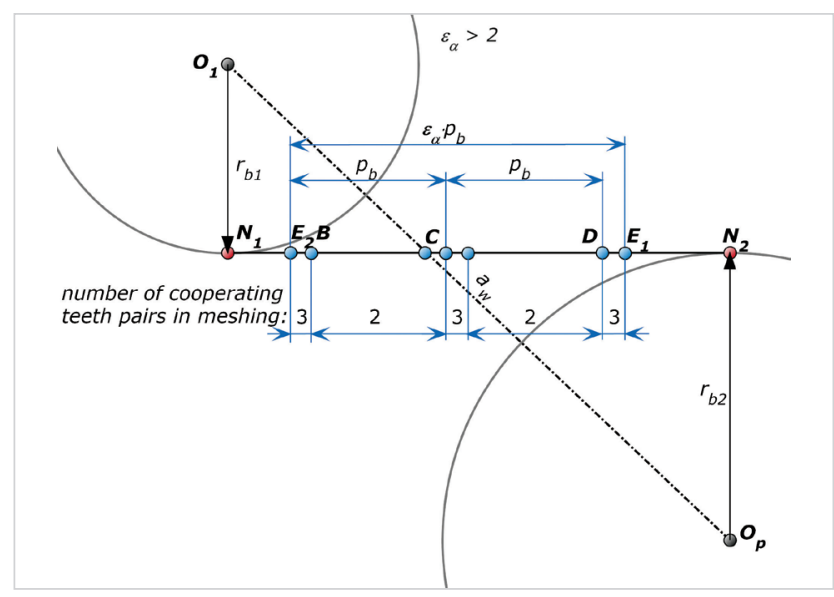

b)

Source: Own study

Figure 3 Characteristic points on the line of contact and method of determining the number of cooperating teeth pairs in the meshing of two external gears

Slika 3. Karakteristične točke na liniji kontakta i metoda određivanja broja zubaca koji djeluju u paru kod zahvatanja dvaju vanjskih zupčanika

The cooperation of a pair of teeth takes place between points $E_{2}$ and $E_{1}$. Depending on the value of transverse contact ratio $\varepsilon_{a^{\prime}}$ to determine the value of total force in meshing transmitted by the analyzed pair of wheels, it is necessary to calculate the forces transmitted by one or more pairs of teeth cooperating in meshing.

For a standard gear meshing of two external wheels is shown in Figure 3 a. In cooperation are one or two pairs of teeth. When is used a non-standard gear type, called High Contact Ratio (HCR) [19], it is possible to see the situation presented in Figure $3 \mathrm{~b}$. In this case, at the same time in cooperation are two or three pairs of teeth. HCR has an important influence on the toothed gear work quality improvement. To unify the calculation algorithm, the theoretical division of the line of contact is always into three parts with the same length. In each of these parts of contact line can be only one pair of teeth at a time. Characteristic points on the line of contact in the meshing of internal gear are presented in Figure 4.

In each calculation step, the coordinates of the teeth cooperation points, designated $\rho_{1^{\prime}} \rho_{2^{\prime}}$ and $\rho_{3^{\prime}}$ are determined. These are the distances of these points from point $E_{2}$ (Figure 3 ), where:

where:

$$
\begin{gathered}
\rho_{2}=\rho_{1}+p_{b}[\mathrm{~mm}] \\
\rho_{3}=\rho_{1}+2 \cdot p_{b}=\rho_{2}+p_{b}[\mathrm{~mm}]
\end{gathered}
$$

$p_{b}$ - base pitch $[\mathrm{mm}]$.

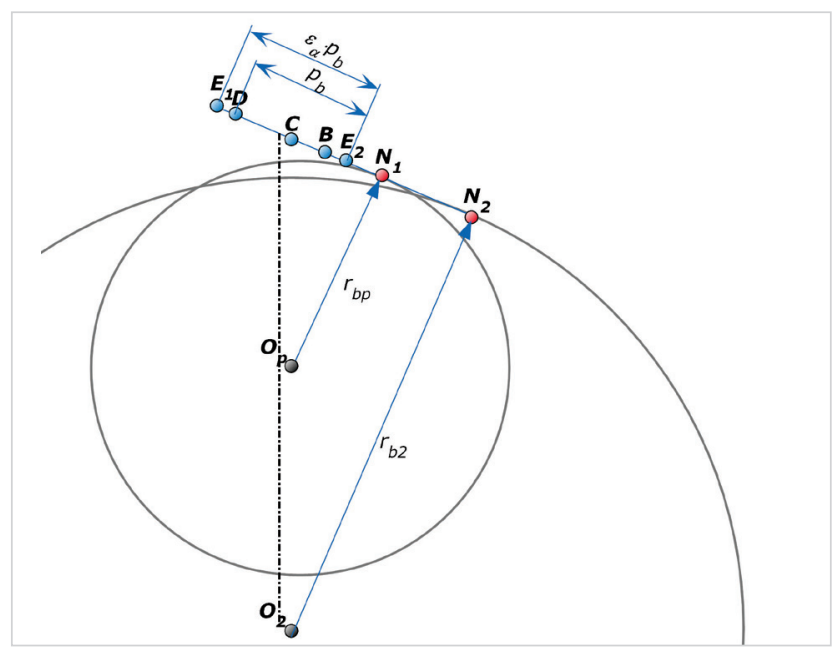

Source: Own study

Figure 4 Characteristic points on the line of contact in the meshing of internal gear pair

Slika 4. Karakteristične točke na liniji kontakta kod zahvatanja unutarnjega para zupčanika

Knowledge of the stiffness characteristics of a pair of teeth (the model uses the method of determination of stiffness of one pair of teeth, developed by Niemann and Baethge) and the cooperation point on the line of contact allow to accurate calculations of the force in meshing. The calculations take into account the angular displacements of wheels and shafts, deviations and modification of the meshing, as well as the occurrence of any local damage on the value of tooth deflection.

Figure 5 shows examples of time courses of forces in the meshing of a sun gear with one of the planetary wheels and the meshing of one of the planetary wheels with an internal gear. The graph was obtained as a result of simulation of a power transmission system with a planetary gear without taking into account the imperfections of meshing.

The changes in the value of force transmitted by successive pairs of cooperating teeth in presented time courses result from changes in total stiffness of meshing, which depend from point of cooperation on the line of contact of every pair of teeth and the variable number of pairs of teeth in meshing. The cooperation intervals of one and two pairs of teeth are clearly visible. 

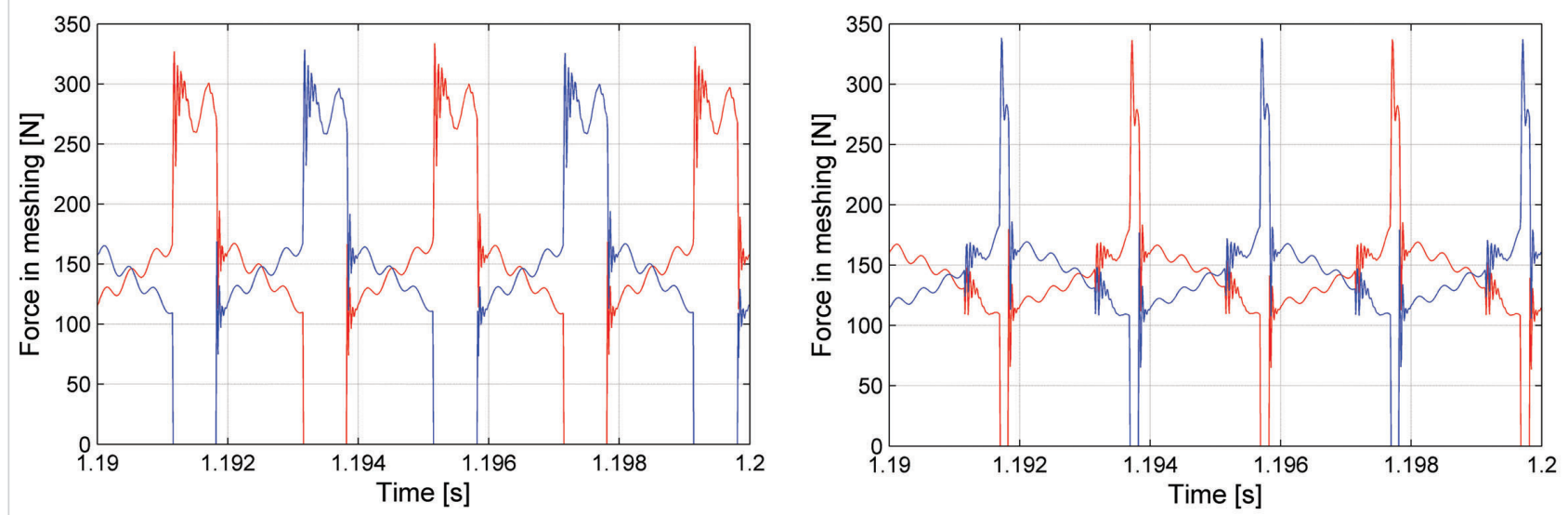

Source: Own study

Figure 5 Exemplary time courses of forces in meshing: a) a sun wheel with one of the planetary wheels, b) an internal gear with one of the planetary wheels; the rotational speed of the input shaft $n_{1} \approx 1457$ rpm; gear without pitch deviations

Slika 5. Ogledni protoci snaga kod zahvata: a) sunčani kotač s jednim od planetarnih kotača, b) interni zupčanik s jednim od planetarnih kotača; rotacijska brzina inputa osovine $n_{1} \approx 1457$ okretaja u minuti (ne uzevši u obzir vršne devijacije)

Developed model, after its proper tuning, enables to obtain the real values among others displacements, velocities, and accelerations of individual elements of the system as a function of time, time courses of forces in meshing, courses of forces transmitted by individual pairs of teeth, as well as courses of forces acting on bearings. The model allows also for simulations of many combinations of local damages of teeth and bearings. For future research, it was also introduced the ability of simulations of wear of working surfaces of teeth. The method of wear simulations with the use of the dynamic model of toothed gear is presented among others in work [35].

After creating a power transmission system diagram and entering the data required by individual blocks, in the next stage there are realized numerical calculations in the Simulink module under the assumed conditions. Standard functionalities of the used simulation environment, like time of simulation, algorithms for solving equations, etc. are naturally available.

Figure 6 presents an example of the time course of torque and rotational speed of the electric engine, obtained during the simulation of the power transmission system with use an expanded description of the engine. Torque oscillations in the starting phase of toothed gear work are particularly visible.

Figure 7 shows the part of the block responsible for calculating the basic parameters of tooth cooperation (numbers of cooperating teeth, location of cooperation points on the line of contact, values of deviations and modification parameters, teeth stiffness, etc.) in the planetary gear meshing.

\section{EXAMPLES OF RESULTS OF RESEARCH CARRIED OUT WITH USE OF THE MODEL / Primjeri rezultata istraživanja provedenoga uz korištenje modela}

At the beginning of a series of various research, carried out with the use of the model, selected calculation results compared with the results of measurements. At the laboratory on the test stand measured torsional vibration velocities of the output shaft of the gear, connected to the planetary gear yoke. The angular position of sun shaft determined with a use position marker connected to the gear allowed averaging of recorded signals. An example of a time courses of recorded signals: torsional vibration velocity of the output shaft and a position marker of the input shaft shows Figure 8.

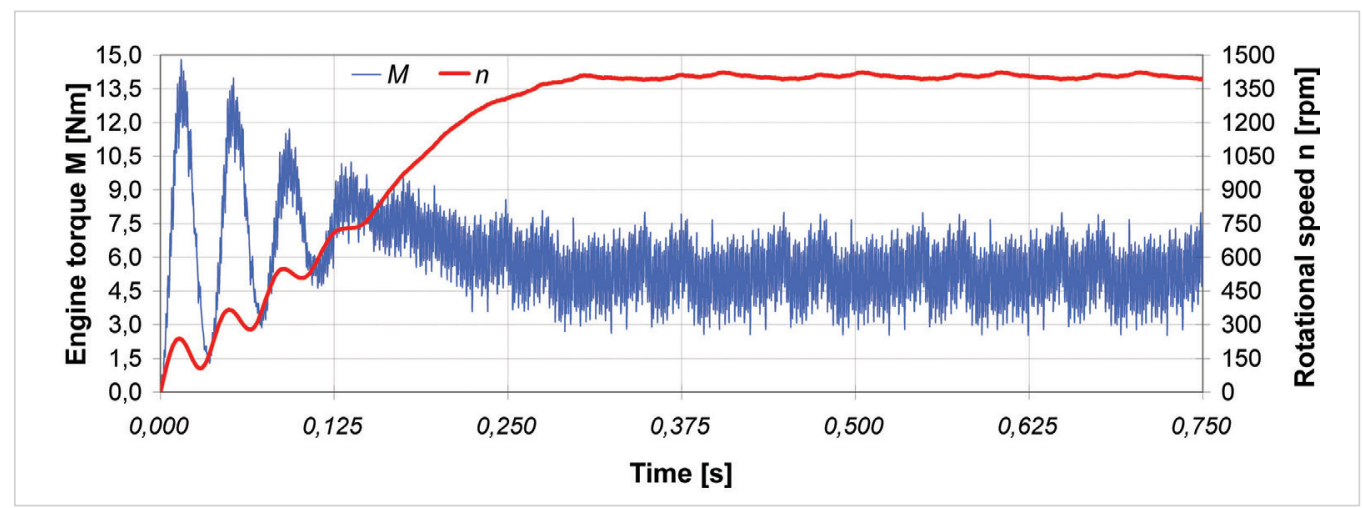

Source: Own study

Figure 6 Time courses of electromagnetic torque and rotational speed determined during the start phase of the engine driving power transmission system

Slika 6. Vremena elektromagnetskoga zakreta i rotacijska brzina određena za vrijeme početne etape sustava transmisije porivne snage 


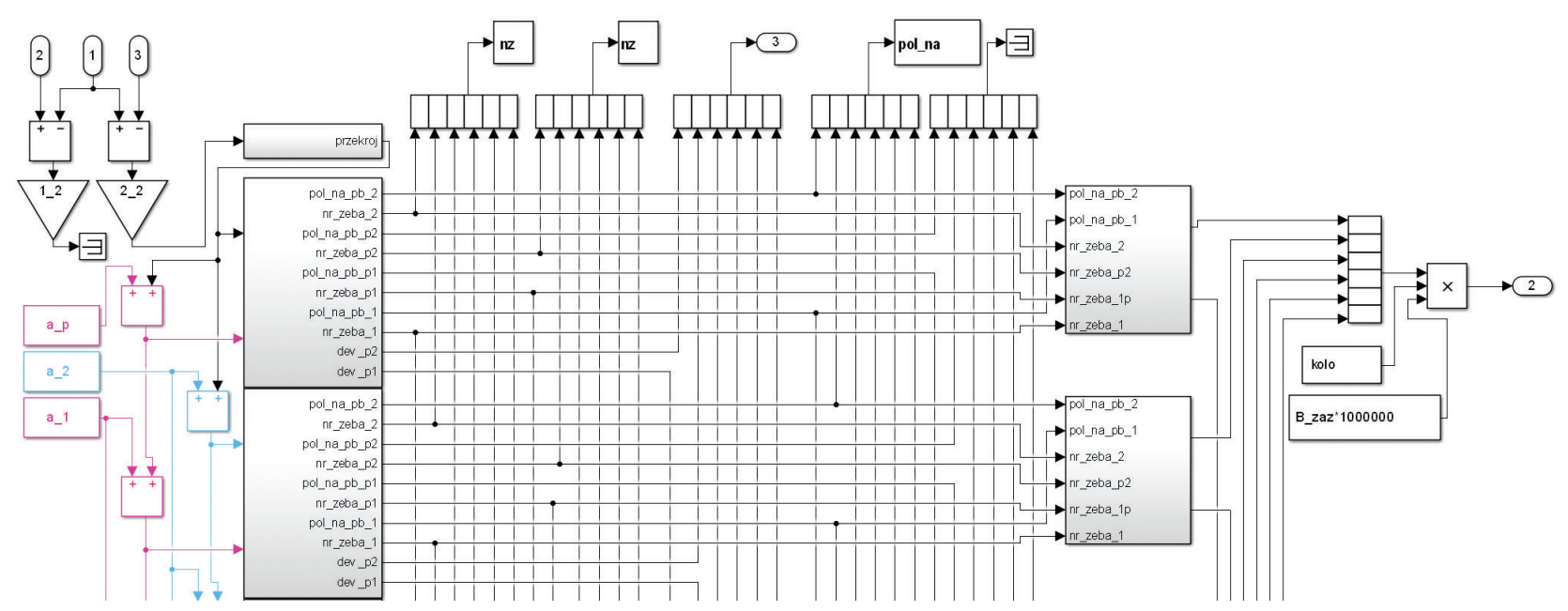

Source: Own study

Figure 7 Part of the simulation block of meshing in planetary gear

Slika 7. Dio simulacijskoga bloka zahvatanja kod planetarnog zupčanika
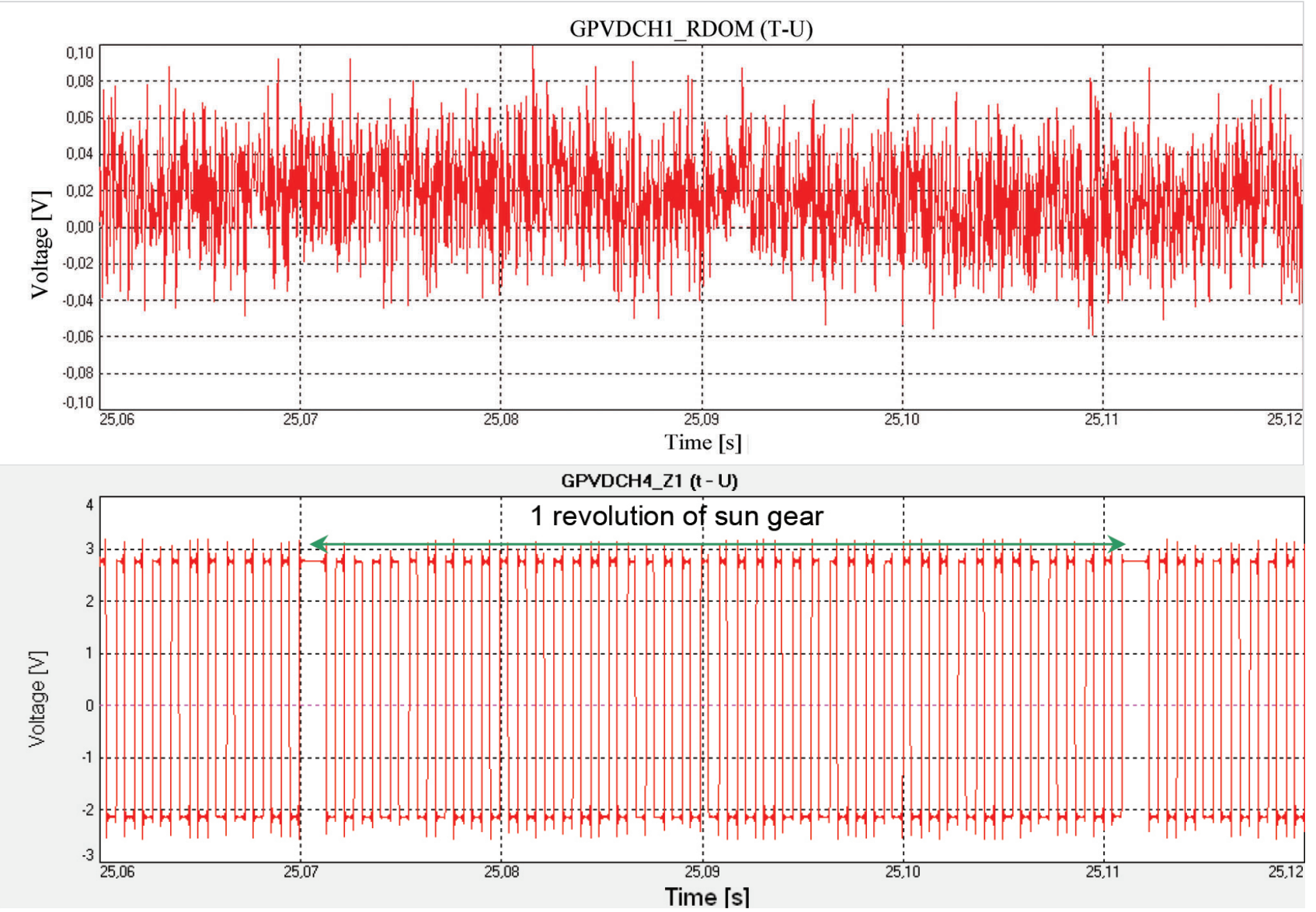

Source: Own study

Figure 8 Selected voltage-time courses: a) torsional vibration velocity of the output shaft, b) marker A of the input shaft position; input shaft speed $n_{1} \approx 1467 \mathrm{rpm}$

Slika 8. Odabrani tijek voltaže: a) torzijska brzina vibracije outputa osovine, b) marker A inputa pozicije osovine; brzina inputa osovine $n_{1}$ $\approx 1467$ okretaja u minuti

The laboratory and numerical research were realized for 5 different velocities of input shaft - from $n_{1} \approx 500$ to $1600 \mathrm{rpm}$. Planetary gear worked at the nominal load - output torque was equal $\sim 35 \mathrm{Nm}$. Information about the position of sun shaft allowed for averaging calculated and measured signals.

The simulation research took into account the determined parameters of the real power transmission system, including toothed gear geometry (Table 1), tooth deviations, type of bearings, masses and moments of inertia. The calculations made for the same rotational speeds and the same load, which during measurements on the laboratory test stand. Numerical calculations took into account the type and temperature of the oil in the toothed gear. 
Table 1 Geometrical parameters of the toothed wheels mounted in analyzed planetary gear Tablica 1. Geometrijski parametri nazubljenih kotača postavljenih na analizirani planetarni zupčanik

\begin{tabular}{|l|r|r|r|r|}
\hline Number of teeth & & Sun gear $(1)$ & Planetary wheel $(p)$ & \multicolumn{1}{c|}{ Internal gear $(2)$} \\
\hline Module & $z_{1^{\prime}} z_{p^{\prime}} z_{2}[-]$ & 27 & 38 & -102 \\
\hline Nominal pressure angle & $m[\mathrm{~mm}]$ & & 1,5 & \\
\hline Base diameter & $a_{0}\left[{ }^{\circ}\right]$ & & 20 & $-143,8$ \\
\hline Root diameter & $d_{b 1^{\prime}} d_{b p^{\prime}} d_{b 2}[\mathrm{~mm}]$ & 38,1 & 53,6 & $-155,3$ \\
\hline Reference diameter & $d_{f 1^{\prime}} d_{f p^{\prime}} d_{f 2}[\mathrm{~mm}]$ & 36,8 & 51,8 & $-153,0$ \\
\hline Tip diameter & $d_{1^{\prime}} d_{p^{\prime}} d_{2}[\mathrm{~mm}]$ & 40,5 & 57,0 & $-148,6$ \\
\hline Face width & $d_{a 1^{\prime}} d_{a p^{\prime}} d_{a 2}[\mathrm{~mm}]$ & 43,4 & 58,5 & 28 \\
\hline
\end{tabular}

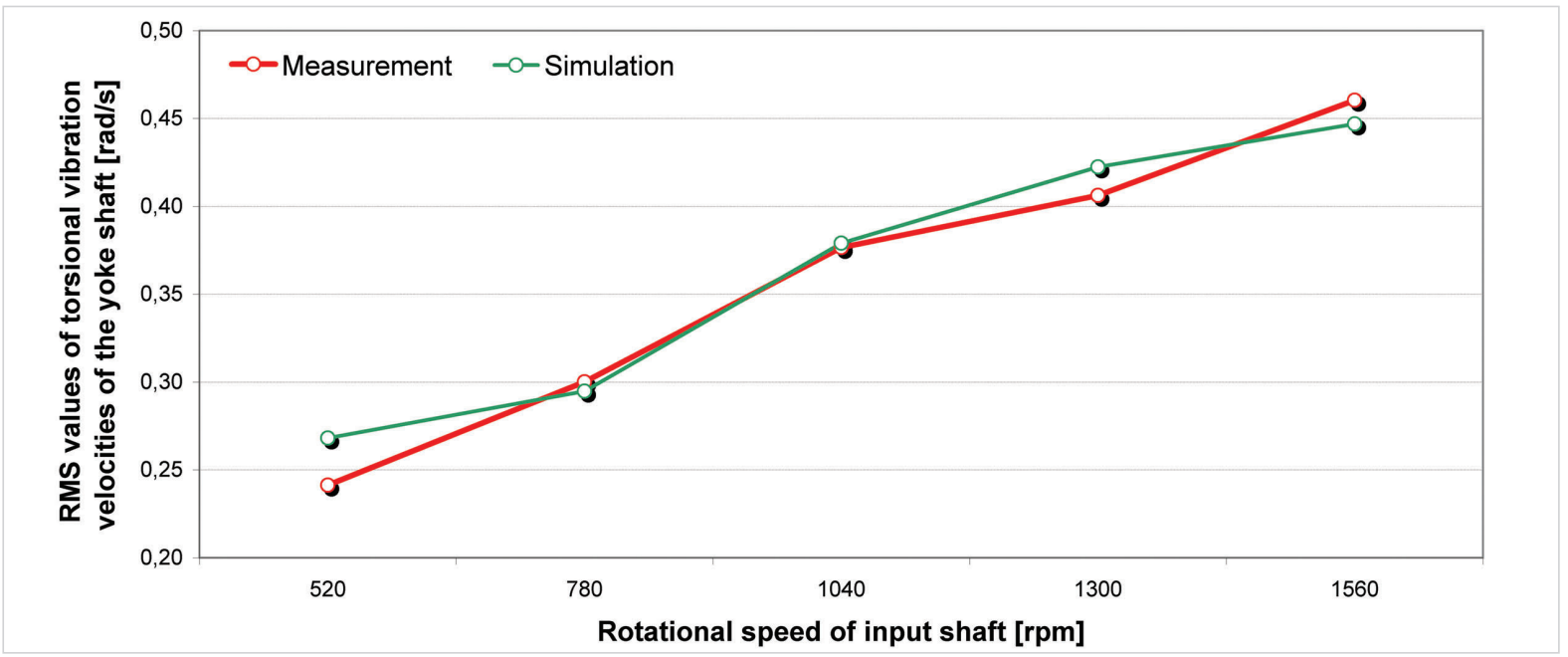

Source: Own study

Figure 9 Comparison of RMS values of torsional vibration velocities of the yoke shaft as a function of velocities of the input shaft, obtained from measurements and numerical calculations for the transmission load of about 35 [Nm]

Slika 9. Usporedba RMS vrijednosti brzine torzijske vibracije osovine kao funkcija brzine inputa osovine dobivene izmjerama i numeričkim kalkulacijama za transmisiju opterećenja od oko $35 \mathrm{Nm}$

Next, the obtained results of simulation tests compared with the corresponding results of measurements made using a laser vibrometer. Figure 9 presents a comparison of RMS values of torsional vibration velocities of the output shaft for the nominal load and different velocities of the input shaft.

Analysis of the values presented on the graph allows for a statement that the results of the simulation are similar to the results of measurements realized on a real object. The largest difference occurred for the lowest rotational speed in the tests, equal for the input shaft of the transmission (sun gear shaft) $n_{1} \approx$ 517 [rpm] and for the output shaft (yoke shaft) around 105 [rpm].

A developed dynamic model of the drive system with the planetary allows also for calculations of the values of dynamic surplus coefficient in all meshing of gear. The dynamic surplus coefficient, marked with the symbol $K_{d^{\prime}}$ define the ratio of dynamic force value $F_{d y n}$ to the static value $F_{\text {stat }}$ of meshing force according to the formula:

$$
K_{d}=\frac{F_{d y n}}{F_{\text {stat }}}[-]
$$

where:

$F_{d y n}$ - dynamic meshing force $[\mathrm{N}]$,

$F_{\text {stat }}$ - static meshing force $[\mathrm{N}]$.

By using this functionality, other numerical research determined the value of the $K_{d}$ coefficient according to the above formula separately for each subsequent pair of teeth located in each meshing and also for every wheel.

After the simulation, the mean from the calculated dimensionless values of $K_{d}$ in each meshing was calculated. This simple statistical processing of the results allows avoiding a situation in which one maximum value determines the final value of the coefficient. In the analyzed case, $K_{d}$ values were calculated separately for 6 meshings (meshings of gear with three planetary gears: $1-p_{1^{\prime}} 1-p_{2^{\prime}} 1-p_{3^{\prime}} p_{1}-2, p_{2}-2, p_{3}-2$, where 1 sun gear, 2 - internal gear, $p_{1}, p_{2}, p_{3}$ - planetary wheels). Figure 10 presents obtained results for a sun gear (mean value from $\left.K_{d(1-p 1)^{\prime}} K_{d(1-p 2)^{\prime}} K_{d(1-p 3)}\right)$ in a wide range of rotational speeds of the planetary gear input shaft $n_{1}=1800 \div 10000 \mathrm{rpm}$.

The last of the sample research results presented in the article refers to the determination of the parameters of the tooth profile modification to effectively reduce the level of dynamic phenomena occurring in the toothed gear. As a result of load, during power transmission system operation, the tooth changes its geometry. Tooth profile modification is one of the basic methods of gear vibroactivity reduction. Optimization of tooth profile with the use of a dynamic model presents work [36].

Analyzing the time courses of forces in the meshing of the sun gear with one of the planetary wheels (shown in Figure 11) 


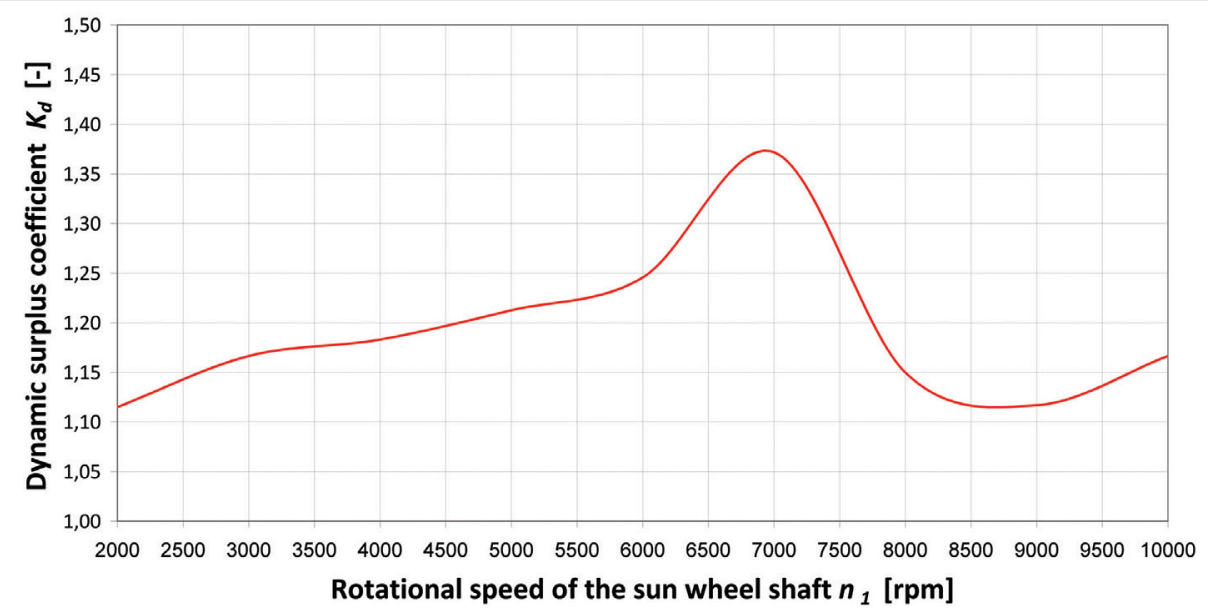

Source: Own study

Figure 10 Dynamic surplus coefficient $K_{d}$ in the range of sub-resonant rotational speeds of the sun wheel shaft $\left(n_{\tau}\right)$ - simulation results Slika 10. Dinamički dodatni koeficijent $K_{d}$ kod podrezonantnih rotacijskih brzina osovine $\left(n_{1}\right)$-rezultati simulacije

--- force transferred by odd teeth of sun gear $\quad$---- force transferred by even teeth of sun gear

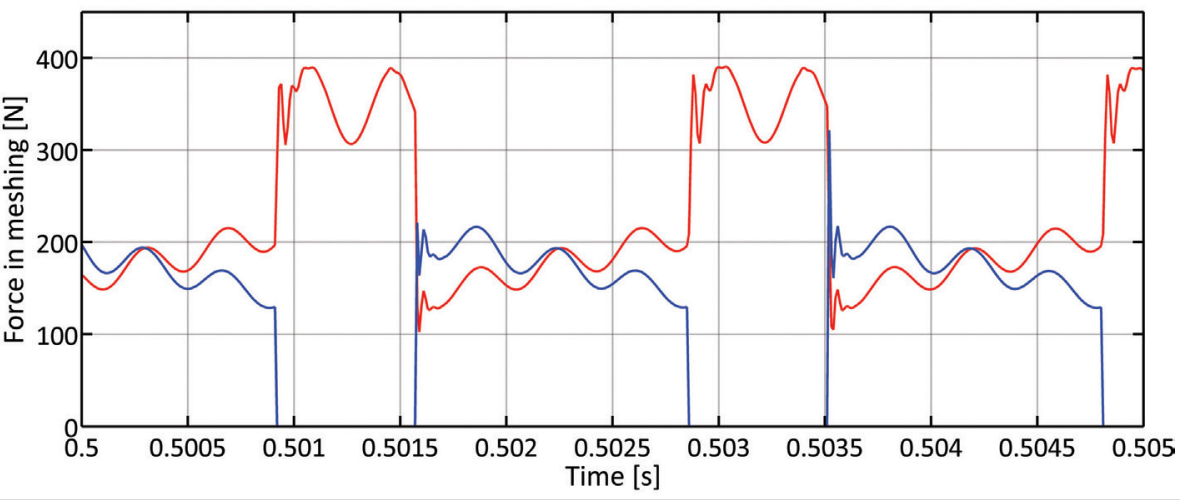

Source: Own study

Figure 11 Time courses of forces in the meshing of the sun gear with one of the planetary wheels; the rotational speed of the input shaft $n_{1} \approx 1457 \mathrm{rpm}$; gear without profile modification of teeth and pitch deviations

Slika 11. Tijek vremena snaga zahvata osovine s jednim od planetarnih kotača; rotacijska brzina inputa osovine $n_{1} \approx 1457$ rpm; zupčanik bez modifikacije profila zupca i vršne devijacije

without applied profile modification, are clearly visible changes of the number of cooperated teeth in the analyzed meshing.

Figure 12 presents the obtained time courses of forces in meshing after assuming the depth of sun gear tooth modification at a level close to the value of the static deflection of the teeth. Maxima of forces were reduced, which also reduces the value of the dynamic surplus coefficient $K_{d}$.

The values of the $K_{d}$ coefficient for toothed gears without profile modification and with a correctly selected parameters of profile modification of the sun gear summarize Table 2 . In

\section{--- force transferred by odd teeth of sun gear $\quad$--- force transferred by even teeth of sun gear}

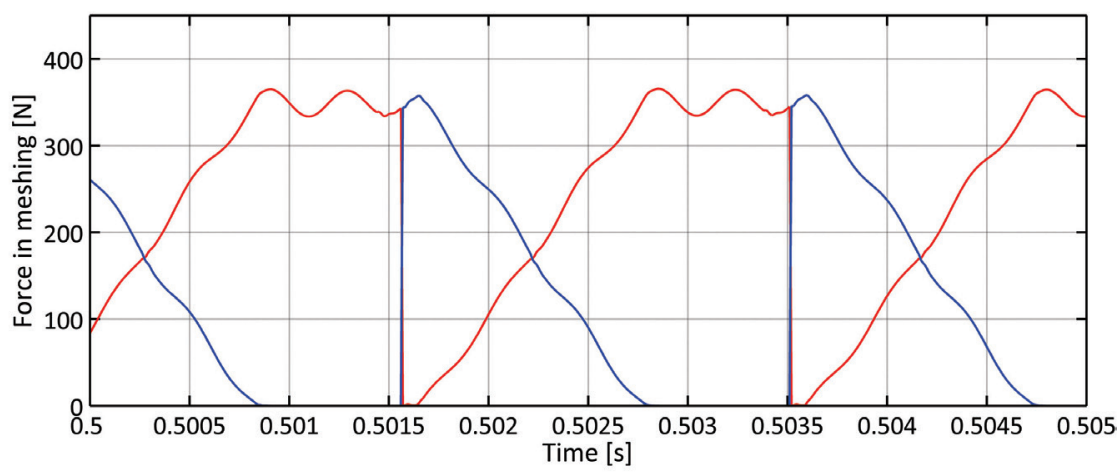

Source: Own study

Figure 12 Time courses of forces in the meshing of the sun gear with one of the planetary wheels; the rotational speed of the input shaft $n_{1} \approx 1457 \mathrm{rpm}$; gear with profile modification of teeth and without pitch deviations

Slika 12. Tijek vremena snaga zahvata zupčanika s jednim od planetarnih kotača; rotacijska brzina inputa osovine $n_{1} \approx 1457$ rpm; zupčanik s modifikacijom profila zubaca i bez vršnih devijacija 
Table 2 Comparison of dynamic surplus coefficient $K_{d}$ values - the meshing of sun gear (1) with one of three simulated planetary wheels $(p)$ and the meshing of a planetary wheel $(p)$ with an internal gear (2); gears without modification and with modification of the tooth profile

Tablica 2. Usporedba dinamičkog dodatnog koeficijenta $K_{d}$ vrijednosti - zahvat sunčanoga zupčanika (1) sjednim od tri simulirana planetarna kotača (p) izahvat planetarnoga zupčanika (p) s internim zupčanikom (2); zupčanici bez modifikacije is modifikacijom profila zupca

\begin{tabular}{|c|c|c|c|c|c|c|}
\hline \multirow[b]{2}{*}{ Toothed gear pair } & \multirow[b]{2}{*}{ Pitch deviation } & \multirow[b]{2}{*}{$\begin{array}{c}\text { Profile } \\
\text { modification }\end{array}$} & \multicolumn{4}{|c|}{ Dynamic surplus coefficient in: } \\
\hline & & & \multicolumn{2}{|c|}{$\begin{array}{l}\text { meshing of sun gear }(1) \\
\text { with planetary wheel }(p) \\
\qquad K_{d(1-p)}[-]\end{array}$} & \multicolumn{2}{|c|}{$\begin{array}{c}\text { meshing of planetary wheel }(p) \\
\text { with an internal gear }(2) \\
K_{d(p-2)}[-]\end{array}$} \\
\hline 1 & No & No & 1,08 & \multirow{2}{*}{$\begin{array}{l}\text { Reduction } \\
\sim 6,5 \%\end{array}$} & 1,13 & \multirow{2}{*}{$\begin{array}{c}\text { Reduction } \\
\quad \sim 9,7 \%\end{array}$} \\
\hline 2 & No & Yes & 1,01 & & 1,02 & \\
\hline 3 & Yes & No & 1,27 & \multirow{2}{*}{$\begin{array}{l}\text { Reduction } \\
\sim 12,5 \%\end{array}$} & 1,33 & \multirow{2}{*}{$\begin{array}{l}\text { Reduction } \\
\sim 7,5 \%\end{array}$} \\
\hline 4 & Yes & Yes & 1,11 & & 1,23 & \\
\hline
\end{tabular}

Source: Own study

both cases are presented results for idealized (without pitch deviations) and real (with pitch deviations) toothed gear.

The study showed, that the correct modification effect of the tooth profile in the simulated toothed gears, requires smaller depths of modification than it is indicated in the literature. The modification in the ideal gear, without pitch deviations, allowed obtaining the values of dynamic forces only slightly exceeds the values of static force. In real toothed gears with various production and assembly imperfections, the profile modification effect also allows for significant improvement. The reduction of the excess of dynamic forces in the examined meshing of the modified sun wheel reached a dozen or so percent and also contributed to lower dynamic loads in the meshing of the unmodified internal gear. The use of modification in all meshing allows achieving even better results; however, it contributes to the increase in the cost of gear manufacturing.

\section{CONCLUSION / Zaključak}

The simulation program presented in the paper is still being developed, which will contribute to further extending its scope of application. The completed stages allow for using of the program into the task of construction optimization of drive systems with two types of gears. Both versions of the dynamic model - with simply one-stage cylindrical toothed gear and with planetary gear were tuned to real objects.

The assumed universality of the program allows its application to the conventional power transmission systems with an internal combustion engine as well as systems powered by an electric motor. Both are applicable in means of transport, including means of maritime transport. Implementations of the power transmission system driven by an electric motor are also already known especially in smaller ships.

In both cases of power transmission systems in means of maritime transport, the model can be used as a useful tool in the design of a new system, as well be useful in optimizing existing construction, especially in terms of reducing vibration and noise from the engine to the screw propeller. It can also help in the development of vibroacoustic diagnostic algorithms of power transmission systems, which may be economically important for shipowners.

Presented in the article are the results of the research, which confirm the wide application possibilities of the identified models, which already have been used in many different studies. Some of them aimed to support the task of diagnosing gears, which has been done by conducting a series of simulations with various local damages of wheels and bearings. The obtained results of numerical simulations are consistent with the results of the measurements carried out on the real objects. The wide range of research capabilities of the program and the number of parameters included in the dynamic models caused, that not all information regarding the conditions of the research was listed. The details of many research realized with developed dynamic models will be presented in the following publications.

\section{REFERENCES / Literatura}

[1] Liang X. H., Zuo M. J., Feng Z.: Dynamic modelling of gearbox faults: A review. Mechanical Systems and Signal Processing, vol 98, 2018, 852-876, 2018. https://doi.org/10.1016/j.ymssp.2017.05.024

[2] Peruń G.: Toothed gear dynamic model as a tool for assist diagnosis its technical condition. Solid State Phenomena; Vol. 236, 2015. https://doi. org/10.4028/www.scientific.net/ssp.236.228

[3] Gui Y., Han O. K., Chu F. L.: A vibration model for fault diagnosis of planetary gearboxes with localized planet bearing defects. Journal of Mechanical Science and Technology, Volume 30, Issue 9, 4109-4119, 2016. https://doi. org/10.1007/s12206-016-0823-0

[4] Chen ZG., Shao Y. M.: Dynamic simulation of planetary gear with tooth root crack in ring gear. Engineering Failure Analysis, Volume 31, 8-18, 2013. https://doi.org/10.1016/j.engfailanal.2013.01.012

[5] Liu XZ., Yang YH., Zhang J.: Resultant vibration signal model based fault diagnosis of a single stage planetary gear train with an incipient tooth crack on the sun gear. Renewable Energy, Volume 122, 65-79, 2018. https://doi. org/10.1016/j.renene.2018.01.072

[6] Cheng Z., Hu N. Q., Zhang X. F.: Crack level estimation approach for planetary gearbox based on simulation signal and GRA. Journal of Sound And Vibration, Volume 331, Issue 26, 5853-5863, 2012. https://doi.org/10.1016/j. jsv.2012.07.035

[7] Al-shyyab A., Kahraman A.: Non-linear dynamic analysis of a multi-mesh gear train using multi-term harmonic balance method: period-one motions. Journal of Sound and Vibration 284/2005. https://doi.org/10.1016/j. jsv.2004.06.010

[8] Al-shyyab A., Kahraman A.: Non-linear dynamic analysis of a multi-mesh gear train using multi-term harmonic balance method: sub-harmonic motions. Journal of Sound and Vibration 279/2005. https://doi.org/10.1016/j. jsv.2003.11.029

[9] Parey A., El Badaoui M., Guillet F., Tandon N.: Dynamic modelling of spur gear pair and application of empirical mode decomposition-based statistical analysis for early detection of localized tooth defect. Journal of Sound and Vibration 294(3)/2006. https://doi.org/10.1016/j.jsv.2005.11.021

[10] Parker R. G., Vijayakar S. M., Imajo T.: Non-linear dynamic response of a spur gear pair: modelling and experimental comparisons. Journal of Sound and Vibration 237(3)/2000. https://doi.org/10.1006/jsvi.2000.3067

[11] Dąbrowski Z., Radkowski S., Wilk A.: Gear dynamics. Research and simulation in operationally oriented design [in Polish: Dynamika przekładni zębatych. Badania i symulacja w projektowaniu eksploatacyjnie zorientowanym]. Wydawnictwo i Zakład Poligrafii Instytutu Technologii Eksploatacji, Warszawa-Katowice-Radom 2000.

[12] Howard I., Jia S., Wang J.: The dynamic modelling of a spur gear in mesh including friction and a crack. Mechanical Systems and Signal Processing 15(5)/2001. https://doi.org/10.1006/mssp.2001.1414

[13] Jia S., Howard I., Wang J.: The dynamic modelling of multiple pairs of spur gears in mesh including friction and geometrical errors. 6th International Conference on Rotor Dynamics IFToMM. Sydney, Australia 2002. https://doi. org/10.1155/s1023621 x03000423

[14] Korka Z. I., Mituletu I. C.: A Review of Dynamic Models Used in Simulation of Gear Transmissions. Analele Universitatii “Eftimie Murgu” Resita, Anul XXI, nr. $1,165-174,2014$ 
[15] Özgüven H. N., Houser D. R.: Mathematical models used in gear dynamics - a review. Journal of Sound and Vibration 121(3)/1988. https://doi.org/10.1016/ s0022-460x(88)80365-1

[16] Müller L., Wilk A.: Toothed planetary gears [in Polish: Zębate przekładnie obiegowe]. Wydawnictwo Naukowe PWN, Warszawa 1996.

[17] Bartelmus W.: Mathematical modelling and computer simulations as an aid to gearbox diagnostics. Mechanical Systems and Signal Processing 15(5)/2001, p. 855-871. https://doi.org/10.1006/mssp.2001.1411

[18] Bartelmus, W., Grabski, J.: Modelling and Simulation of Gear Systems Dynamics for Supporting Condition Monitoring Using Mathematica. Advances in condition monitoring of machinery in non-stationary operations. Applied Condition Monitoring Volume 4, 375-384, Proceedings Paper of 4th International Conference on Condition Monitoring of Machinery in Non-Stationary Operations (CMMNO), 2016. https://doi.org/10.1007/9783-319-20463-5_28

[19] Skoć A., Němček M., Grzesica P., Moravec V., Spałek J., Tůma J., Wieczorek A.: Identification of dynamic state and durability of gears with high-toothed wheels [in Polish: Identyfikacja stanu dynamicznego i trwałości przekładni zębatych z kołami o uzębieniu wysokim]. Wydawnictwo Politechniki Śląskiej, Gliwice 2008

[20] Kar C., Mohanty A.: Determination of time-varying contact length, friction force, torque and forces at the bearings in a helical gear system. Journal of Sound and Vibration 309/2008. https://doi.org/10.1016/j.jsv.2006.09.031

[21] Łazarz B., Peruń G.:Identification and verification of simulation model of gears working in circulating power system. Diagnostyka nr 4 (52)/2009.

[22] Andersson A., Vedmar L.: A dynamic model to determine vibrations in involute helical gears. Journal of Sound and Vibration 260/2003. https://doi. org/10.1016/s0022-460x(02)00920-3

[23] Dabrowski Z., Batko W., Cioch W.: Model of the gears based on multibody system and its validation by application of non-contact methods. Acta Physic Polonica A, Vol. 123, Is. 6, 2013, p.1016-1019. https://doi.org/10.12693/ aphyspola.123.1016

[24] Markowski T., Noga S., Rudy S.: Numerical Model of Aviation Gearbox Test Rig in a Closed Loop Configuration. Aviation, 14(1)/2010. https://doi. org/10.3846/aviation.2010.01

[25] Chaari F., Fakhfakh T., Haddar M.: Dynamic Analysis of a Planetary Gear Failure Caused by Tooth Pitting and Cracking. Journal of Failure Analysis and Prevention, Vol. 6(2)/2006. https://doi.org/10.1361/154770206x99343
[26] Chaari F., Fakhfakh T., Haddar M.: Numerical simulation of planetary gear failure detection by Wigner-Ville method. Second World Congress on Engineering Asset Management and the 4th International Conference on Condition Monitoring. Harrogate, UK 2007.

[27] Parker R. G., Lin J.: Modeling, Modal Properties, and Mesh Stiffness Variation Instabilities of Planetary Gears. NASA Final Contractor Report 210939, 2001.

[28] Lin J., Parker R. G.: Planetary gear parametric instability caused by mesh stiffness variation. Journal of Sound and Vibration 249(1)/2002. https://doi. org/10.1006/jsvi.2001.3848

[29] Ambarisha V. K., Parker R. G.: Nonlinear dynamics of planetary gears using analytical and finite element models. Journal of Sound and Vibration 302/2007. https://doi.org/10.1016/j.jsv.2006.11.028

[30] Sun T., Hu H. Y.: Nonlinear dynamics of a planetary gear system with multiple clearances. Mechanism and Machine Theory 38/2003. https://doi. org/10.1016/s0094-114x(03)00093-4

[31] Dion J. L., Moyne S., Chevallier, G., Sebbah H.: Gear impacts and idle gear noise: Experimental study and non-linear dynamic model. Mechanical Systems and Signal Processing, Volume 23, Issue 8, 2608-2628, 2009. https:// doi.org/10.1016/j.ymssp.2009.05.007

[32] Guo Y., Parker R. G.: Dynamic modeling and analysis of a spur planetary gear involving tooth wedging and bearing clearance nonlinearity. European Journal of Mechanics - A/Solids, vol 29, issue 6, 1022-1033, 2010. https://doi. org/10.1016/j.euromechsol.2010.05.001

[33] Peruń G.: Influence of the electric motor model selection on the accuracy of simulation of the dynamic states. Trans. Univ. No. 3, Kosice 2012.

[34] Peruń G.: Simulation investigations of influence of tooth depth coefficient on dynamic phenomena in toothed gear. Applied Mechanics and Materials, Vol. 817, 2016. https://doi.org/10.4028/www.scientific.net/amm.817.41

[35] Kahraman A., Ding H.: Interactions between nonlinear spur gear dynamics and surface wear. Journal of Sound and Vibration 307/2007. https://doi. org/10.1016/j.jsv.2007.06.030

[36] Wang Y.: Optimized tooth profile based on identified gear dynamic model Mechanism and Machine Theory 42/2007.https://doi.org/10.1016/j. mechmachtheory.2006.02.011 